\title{
ENERGY DEVELOPMENT: A NEED FOR VISION AND STATESMANSHIP
}

\author{
GEORGE A. BEVAN*
}

\begin{abstract}
Energy demand the world over is increasing, and one of the consequences of this increased demand is a raging debate on energy resources, development, and usage. This article examines the various sources of energy supply (such as coal, hydro-electric power, petroleum products, etc.) and the energy demand requirements in (1) the world, (2) the United States, and (3) Canada, and then discusses the long-range implications of such supply and demand requirements against energy-proven and potential. The author then discusses the problem of resource policy development in Canada today, and in so doing, covers such issues as resource availability; capital requirement; pricing; exporting of energy; etc. Finally, the author proposes a framework for the achievement of a national consensus on energy development and usage for Canada.
\end{abstract}

\section{INTRODUCTION}

Energy development and usage, long taken for granted, has recently commanded the attention of nations and individuals the world over. The quality of the debate has varied widely-often generating more heat than light. Within Canada the subject has divisive overtones. Historians may well look back on the seventies and rank the energy debate high on the list of turning points in the nation's development.

I am reluctant to present to you yet another opinion on energy development on top of the many popular press articles on the subject over the past few months. I have therefore decided that this keynote paper should try to put the energy debate in factual perspective. In doing so I will try to deal with some of the issues under debate in Canada as they relate to the development of Frontier oil and gas reserves. Yet the development of these reserves-notwithstanding popular views to the contrary-cannot be viewed in isolation from other forms or sources of energy, any more than Canada's energy scene can be divorced from that of the United States or from the rest of the world.

The approach of this paper will be three fold:

(1) to set the stage by examining the outlook for energy supply and demand in the world at large, in the United States, and in Canada, against a backdrop of estimated reserves;

(2) to examine energy resources development in Canada in the light of socio-economic and political issues raised to date; and

(3) to outline for consideration a framework for the achievement of a sustainable national consensus on energy development and usage in Canada.

Of necessity, much of what will be said will deal with unknown future possibilities. In the time available, one can only hope to give a deterministic, yet plausible, assessment of events as they can reasonably be assessed at this time.

Energy demand is an outgrowth of human want. But these wants vary widely throughout the world. The simple energy needs of primitive societies are satisfied through the individual family or tribal gathering of vegetable and animal matter to provide fuel for cooking or heating.

* General Manaker-Corporate Planning, Shell Canada I.imited. Toronto, Ontario. 
The needs of more complex, but under-developed societies reflect a degree of specialization in the gathering and distribution of energy for uses which extend to process heating and transportation. Finally, modern society has a host of complicated needs which extends the use of energy fuels in sophisticated transportation and distribution systems or as raw material input. In fact, a high correlation exists between energy consumption on the one hand, economic activity and the material well-being of society on the other.

In Canada today, energy demand is created by switching on a light as we arise in the morning, taking a hot shower, having toast and coffee and driving to office, factory or school where we rely on endless forms of energy consuming devices. On and on the process goes, until we get home, adjust the thermostat if we're chilly, flick on the television set, or turn on our electric blanket as we tumble into bed. Consumers have come to expect, almost as a right, that energy will be available at their fingertips.

Energy companies are in the business of satisfying these human wants through the creation of "utility". This "utility" arises through the discovery of raw materials, their conversion into a form, a quantity and quality required as determined, and transported to a place where needed for use at the convenience of a customer at a price proportionate to value perceived. I cannot stress this role too strongly. The energy industries are a response to human want, and not, as the popular press would lead one to believe, wanton exploiters of society's natural resources for private gain. This is not to say they do not pursue their endeavours at a profit, but simply that they seek to achieve those profits through the satisfaction of human wants.

\section{ENERGY SUPPLY AND DEMAND}

\section{The World Scene}

It is against this background that I would like to examine the broad question of World Energy Supply and Demand over the 40-year period 1950-1990, and direct your attention to Chart 1. For purpose of ready comparison all units have been converted on a basis of thermal value to equivalent barrels of oil consumed per day.

This shows that total consumption has more than doubled from 35 to 87 million barrels daily oil equivalent from 1950 to 1970 , and is expected to increase another threefold to 263 million barrels daily oil equivalent by 1990 . Within this framework, oil and gas displaced coal and supplied over two-thirds of the world's energy requirements by 1970 and these fuels are expected to supply this share for the next couple of decades.

Coal failed to grow in line with energy demand from 1950 to 1970 for reasons of economics, convenience and environmental disadvantage. With a continued growth in total energy demand, combined with a limited availability of natural gas, coal is expected to grow in absolute terms, but to decline in relative terms to 1990 .

Hydro-electric power development is slowing down, as potential sites for development become more remote from centres of consumption, and high capital investment renders them only marginally economic at today's cost/price levels. Nevertheless, it is projected that about 540 thousand megawatts of capacity should be in place in 1990. On the 
CHART 1

WORLD ENERGY DEMAND BY FUEL SOURCE

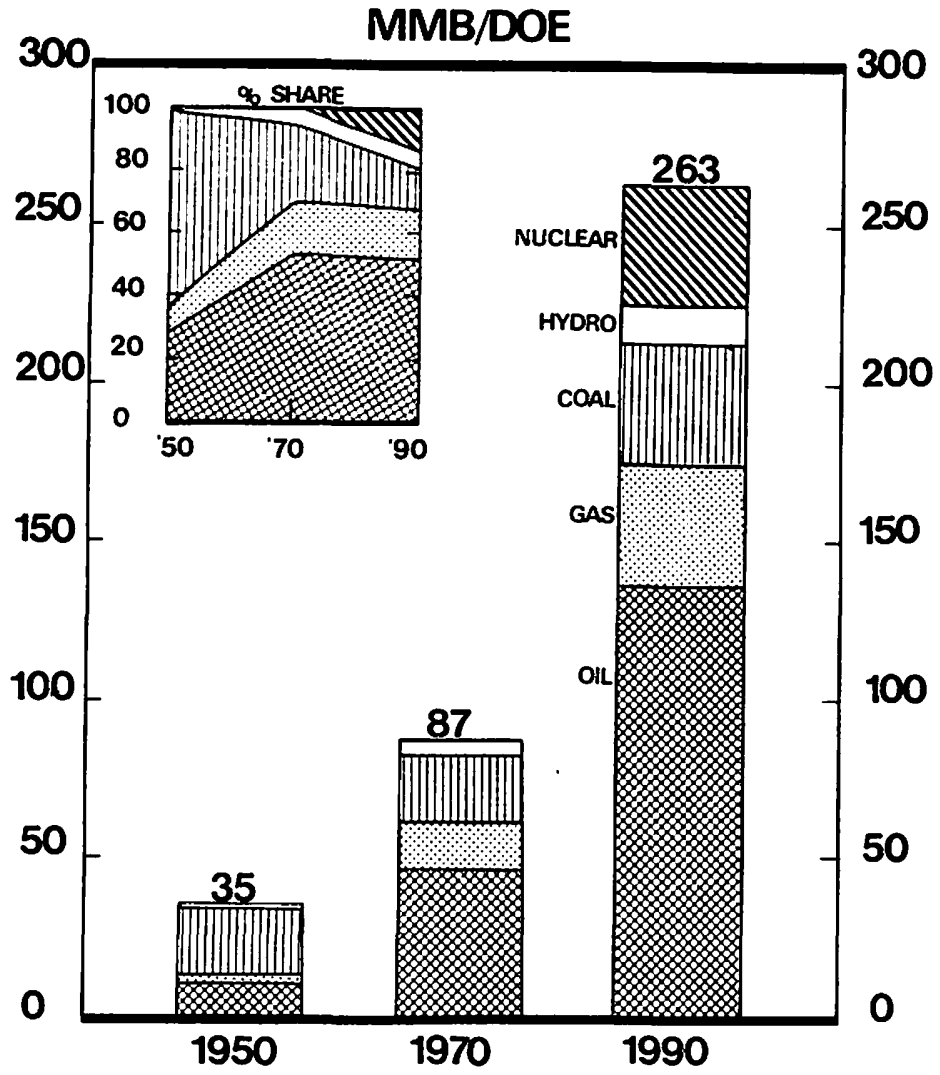

other hand, nuclear power will enjoy an impressive growth from virtually nil in 1970 to roughly 38 million barrels daily oil equivalent by 1990 , when some 1.1 million megawatts of capacity is likely to be operational.

An equally significant factor in considering energy matters is the geographical disparity in supply and demand. In 1970 , about $70 \%$ of the 87 million barrels daily of the world's energy was consumed in industrialized countries that themselves possessed only $48 \%$ of the world's supply, as illustrated on the left of Chart 2. By 1990, consumption in industrialized countries will have more than doubled in absolute terms, but have declined to $63 \%$ of the world's total consumption. Industrialized countries will have increased indigenous supplies by $90 \%$, but their relative share of the world total will have dropped to $30 \%$ some 20 years hence, thus reflecting the growing interdependency of the world.

World oil movements reinforce these observations. In 1970 the Western Hemisphere was relatively self-sufficient, whereas Western Europe and the Far East were largely dependent upon the Middle East and Africa. Similarly projected world oil movements 20 years hence indicate the growing dependence of the Western Hemisphere on Eastern Hemisphere supplies, with a continuing dependence of Western Europe and the Far East on the Middle East and Africa. All three major consuming centres will become predominantly dependent upon the 


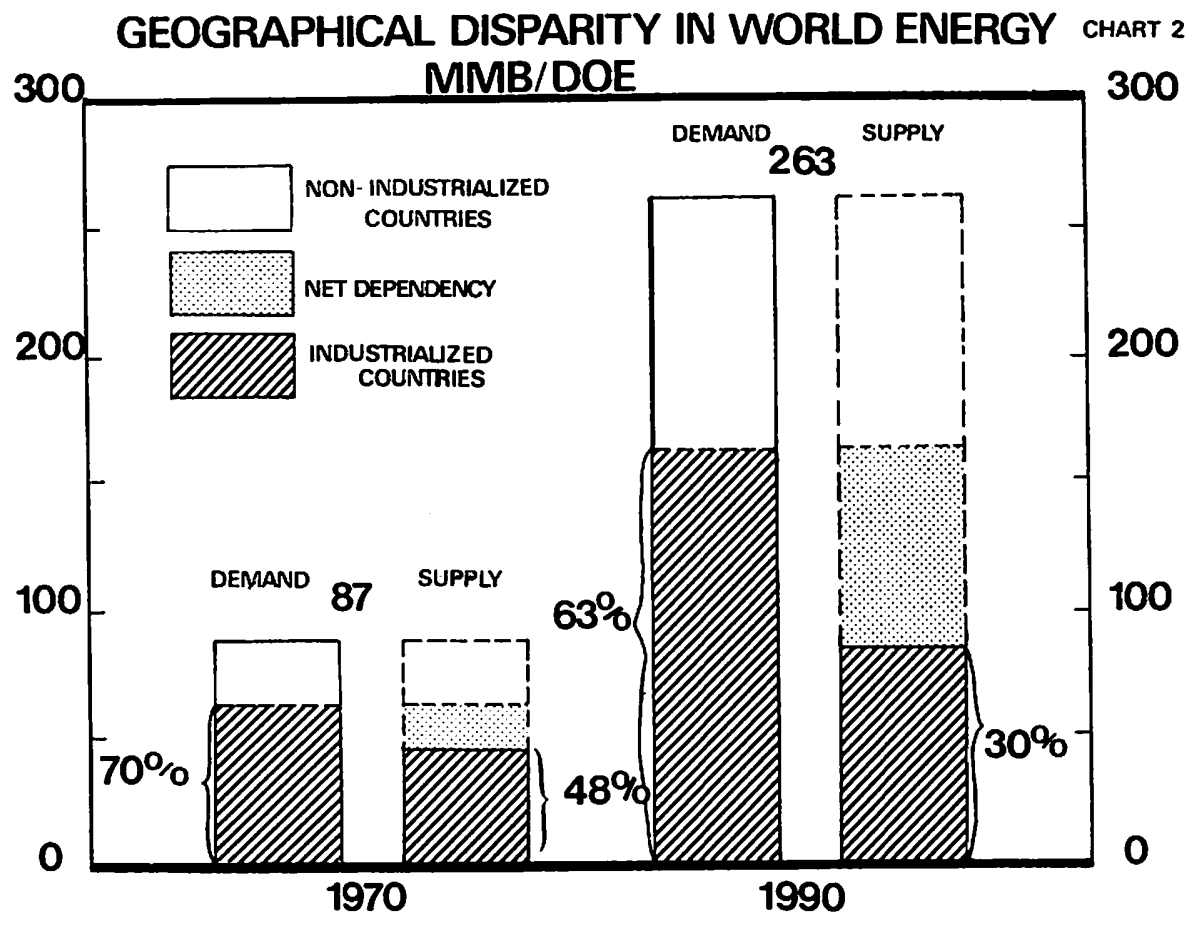

Middle East, where 1990 shipments of oil are expected to be 5 times greater than those of 1970 .

The implications of this are sweeping for shipbuilding and port construction facilities. Over $30 \%$ of the world's oil consumption by 1990 will move in international trade from countries whose governments have announced intentions to obtain a higher share of the value of production. This means increased costs of supply to oil companies, and ultimately to consuming countries. For example, the price of oil in the Middle East has increased 45\% since 1969.

\section{The North American and U.S. Scene}

The North American continent in 1970 accounted for $40 \%$ of the world's energy consumption, and while slipping to about one-third of the world's total consumption by 1990 will increase in absolute terms by almost $2 \frac{1}{2}$ times to a level of roughly 83 million barrels per day of oil equivalent, or marginally less than the entire world consumed three years ago.

In the early days of the oil industry, the United States was a net exporter of oil to the world. However, as prolific overseas fields were brought into production, the U.S. export market disappeared, and its domestic production was shut in. Expanding domestic demand was met in large measure from its own production, but the country allowed itself to become increasingly dependent upon foreign supplies of both oil and gas, despite its large share of the world's coal reserves.

Total energy demand in the United States doubled to 32 million barrels daily oil equivalent in the twenty-year period to 1970 , and is expected to increase nearly $2 \frac{1}{2}$ times to 74 million barrels daily oil 
equivalent by 1990 as shown in Chart 3. Future development of hydroelectric power in the United States holds little promise. However, nuclear power will play a spectacular role in the future, rising from virtually nothing in 1970 to $20 \%$ of total energy by 1990 , requiring about 0.4 million megawatts of installed capacity. The demand for nuclear power could grow faster, but this outlook is predicated upon the longlead-time required for approval and construction of nuclear plantsnearly 10 years.

\section{U.S. ENERGY DEMAND BY FUEL SOURCE ${ }^{3}$ MMB/DOE}

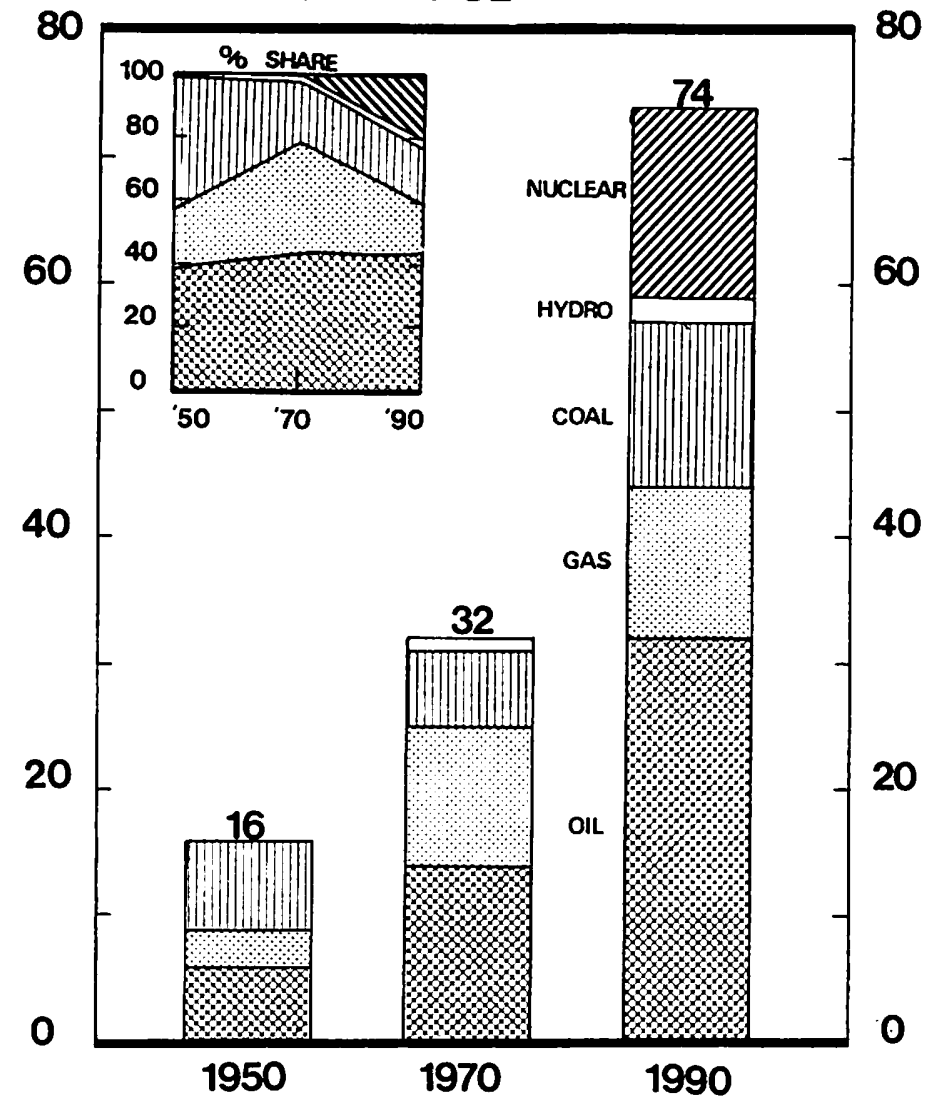

Coal may have a brief comeback in the next few years, as dependence on foreign energy looms large, and nuclear power is slow in coming on line. Yet environmental factors and competitive economics weigh heavily against rapid growth in the use of high sulphur coals which predominate in the United States. However, technological breakthroughs in stack gas scrubbing at economic cost may enhance coal's longer range competitive prospects. It is expected that the volume of coal used by 1990 will increase in line with total energy growth to 4 million short tons per day while maintaining today's share of total energy supply at about $18 \%$.

Oil and natural gas combined, although expected to grow $75 \%$ in absolute terms between 1970 and 1990, will decrease in importance 
in relative terms from over three-quarters of total energy to less than two-thirds by the end of the period. Oil consumption is expected to grow in line with total energy growth, but natural gas will show very little growth over today's volume of 60 billion cubic feet per day, and barely maintain that level of consumption by 1990 . This will result in its share of total energy in the next 20 years being reduced by half.

This peaking of natural gas from the conventional United States domestic supply, at current cost/price levels in about 1975 is shown in Chart 4. It is doubtful if latent demand can be met, despite expected supplements of gas from Alaska and Canada, gasification of domestic coal, imports of liquefied natural gas from the Eastern Hemisphere and synthetic natural gas manufacture from imported condensates or naphthas. Although considerable uncertainty surrounds the precision of the volumes indicated here, this supply constraint both in direction and order of magnitude, is thought to be valid.

\section{U.S. GAS SUPPLIES}

CHART 4

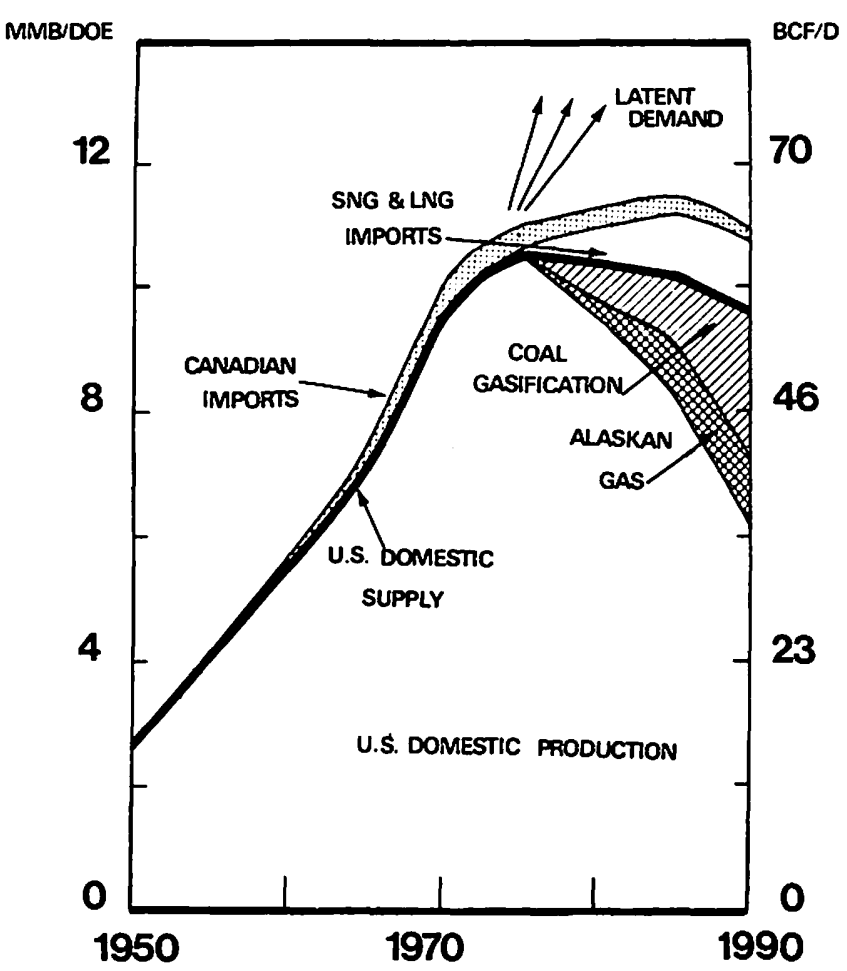

This limited availability of a convenience fuel means escalating cost pressures on remaining gas supplies. Moreover, this creates a need to reach into remote geographical areas, as well as to come to grips with new conversion and transportation technologies-both likely to prove costly and ultimately result in higher commodity prices to consumers.

The United States domestic oil outlook is not much more optimistic than that for natural gas. Oil production in the United States mainland has peaked, at current cost/price levels, as shown on Chart 5. Production 
is expected to decline until Alaska's North Slope Oil reaches the United States West Coast perhaps early in 1977. Although this is the biggest find, and it will permit production of about 2 million barrels daily, it is an increment that will barely sustain United States domestic production at current levels for a few years. Synthetic oil from shale is expected to come on stream in limited volume at high cost, but its contribution to future domestic supplies is thought to be limited. United States shale deposits are located in the arid Western states. Current processes require large quantities of water and economics are uncertain.

CMAFI 5

\section{U.S. PETROLEUM SUPPLY MMB/DOE}

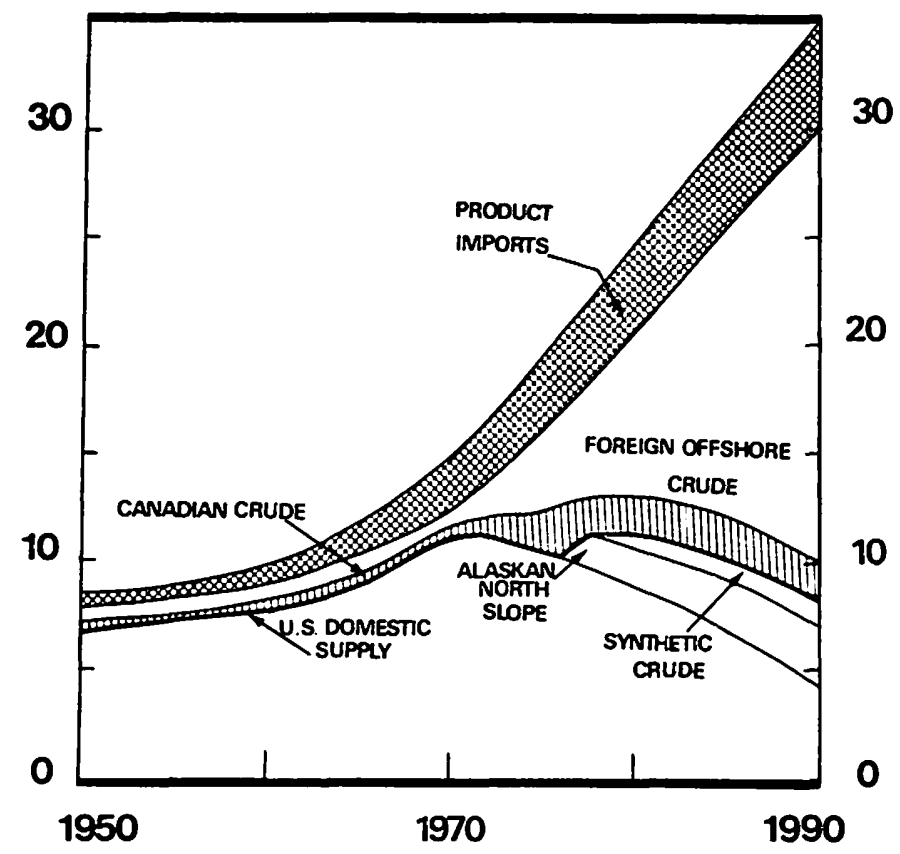

Turning to its immediate neighbours, the United States finds that neither Canadian crude oil imports nor oil product imports from the Caribbean are likely to provide the long-range solution to its energy gap. Thus, the United States is developing a seemingly inevitable dependency -amounting to slightly less than $60 \%$ of total requirements by $1990-$ upon Eastern Hemisphere crude oil. Arguments are advanced that the U.S. cannot let this happen in the interests of its own national securityit would seem that it could be willing to pay an increasing price over the short-term for secure supplies of oil and gas, but for the long-run undertake measures within its domestic control to ensure ultimate security of its energy requirements, such as influencing end-use through urban transit, increased insulation requirements for homes, taxation or rationing, or stepping up alternative domestic sources through funding research projects in coal gasification and liquefactions, etc., or encouraging domestic exploration for oil and gas by higher tariffs. The United States may well have to do something if its balance 
of payments position is to be protected, since for oil and gas alone this could reach a gross outflow of $\$ 30-40$ billion per year by the early 1980 's, offset in part by exports of oil field equipment, investment inflows from producer countries, and by repatriation of earnings from abroad. These situations can readily lead to a higher value being placed upon energy fuels, particularly on oil and gas commodity values.

This growing dependency on Eastern Hemisphere oil, and escalating cost pressures is before taking into account the considerable increase in requirements for refineries to process it, and for ships and port facilities to receive it, and as is suggested in some quarters, an expansion of the Navy to protect such long and potentially vulnerable supply lines.

\section{The Canadian Scene}

In Canada our outlook tends to resemble that of the world at large, more than that of the United States. Energy demand in the period 1950 to 1970 increased $2 \frac{1}{2}$ times and will nearly triple to 8.6 million barrels daily oil equivalent by 1990 , as illustrated on Chart 6 . Oil and gas will

CHART 6

\section{CANADA ENERGY DEMAND BY FUEL SOURCE MMB/DOE}

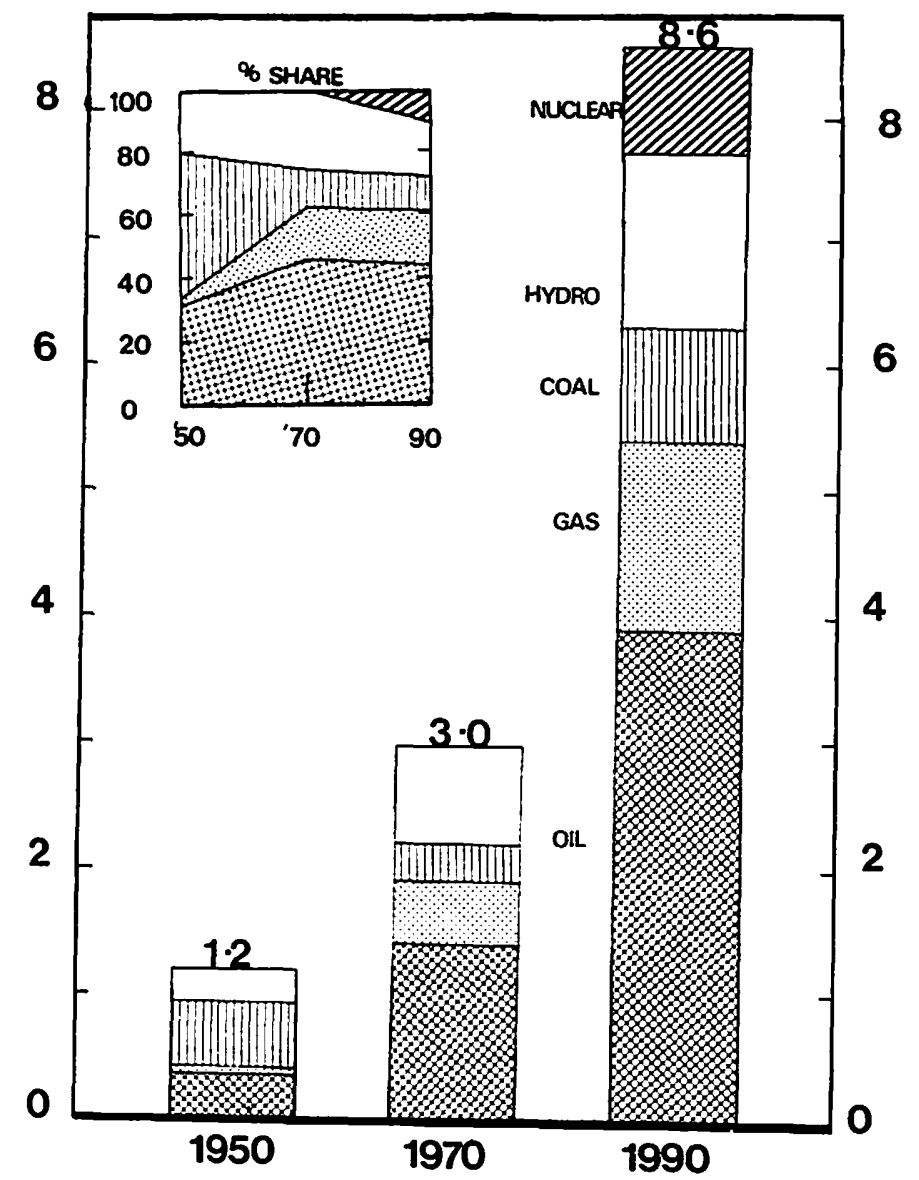


continue to supply $60 \%$ of domestic energy requirements, paralleling total energy growth. Coal will continue to grow in absolute terms, to maintain position at about $12 \%$ of total supply, i.e., some 300 thousand short tons per day.

Hydro developments will continue, but hydro's share of total energy by 1990 will decline to its relative position of the early 1950's. However, nuclear developments hold considerable promise, and are expected to offset hydro's relative decline to supply about $10 \%$ of total energy by 1990 , requiring some 25 thousand megawatts of capacity. This corresponds to a crude oil input equivalent of 0.9 million barrels per day.

Let us examine in greater depth Canada's petroleum situation, where we appear to have exportable surpluses and future potential for enhancing the nation's balance of payments position. In 1970 Canada produced 1.8 trillion cubic feet of natural gas, or 0.85 million barrels per day oil equivalent, about twice as much as was required by Canadian domestic markets. The balance was exported via pipeline to the West Coast and Mid-west regions of the United States. In the opinion of Canada's National Energy Board, insufficient reserves exist in the now producing regions to enable an increase in exports to the United States. This position is disputed by some provincial authorities and by producers. However, domestic transportation and distribution utilities, as well as domestic consumers, stand in support of the Board's position.

Additions to gas reserves in the now producing regions have continued at a relatively high level during the past few years. In 1972, however, remaining reserves dropped significantly, i.e. down 2.5 trillion cubic feet. Exploration in and adjacent to the Foothills Belt-which some consider the most promising part of the producing regions-is being hindered by current well-head prices which are too low to attract risk capital to this region of high cost, sour gas fields. By 1990, production from existing reserves is expected to total about 4.3 billion cubic feet daily, or 740 thousand equivalent barrels of oil per day, having peaked in the late 70's as illustrated on Chart 7. New discoveries in existing regions are projected to augment 1990 production to a total of about 6.9 billion cubic feet per day, or 1.2 million barrels per day oil equivalent.

Discoveries in the Frontier regions hold considerable promise for commercial development by the late 1970's. These reserves will be available to supplement the contribution of the producing regions to domestic requirements as well as providing incremental export capability. Speculations based on preliminary indication of geological potential in the Frontier regions suggests that gas export by the mid 1980's could be more than 9 billion cubic feet per day (1.5 million barrels per day of oil equivalent) in excess of current levels. In support of such exportable production, I am assuming we will be well on the road to proving up northern reserves of over 100 trillion cubic feet capable of being connected to pipelines.

The significance of this development is that reserves are being found in remote areas under high cost operating conditions. But when reserves from the North are added to those previously considered by the National Energy Board, I think it reasonable to assume that Canada will again be deemed to have reserves well beyond its own reasonably foreseeable requirements, as implied by the comparison of production capability and domestic consumption shown on Chart 7. I expect that exports, under controlled conditions, will be authorized. 


\section{PRODUCTION POTENTILL FOR CANADIAN MARKETED GAS}

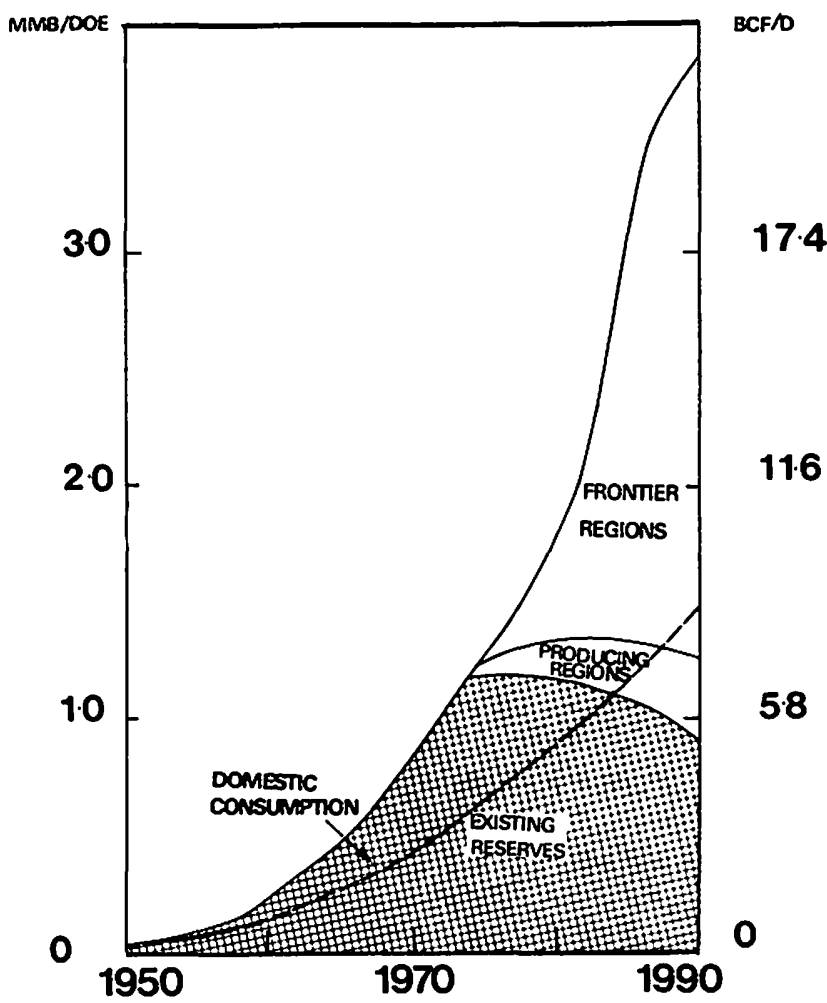

High cost Arctic gas will pass established gas producing areas on route to market, thereby creating upward pressure on gas prices in these regions. This could also attract further exploration capital to search for deep or elusive gas reserves previously overlooked. All of this will lead initially to rising energy costs for consumers, but ultimately higher prices should bring forth more supplies, lead to a sorting out of uneconomic end-uses and settle around a competitive commodity value in each major market.

Arguments have been advanced in this connection that gas prices in established producing regions should only escalate modestly, if at all. However, this could ultimately lead Canada to a position similar to that in which the United States finds itself today where, after years of regulation of domestic gas prices at unrealistically low levels, it has induced uneconomic consumption while failing to attract sufficient risk capital to effect new discoveries. The United States now faces the consequences in supply constraints, declining domestic production, rising imports and higher costs.

The oil situation in Canada is also responsive to world conditions within a framework of broad regulation-the national oil policy. Canada, by these regulations, is divided into two oil supply orbits. The area west of the Ottawa Valley, with minor exceptions, is reserved to Canadian 
crude oil and products. The area east of this line cannot be reached economically by Canadian crude oil and is served by imported crude oil and/or products. Consumers in this eastern orbit experience the competitive benefits of world pricing. Temporary surpluses have often led to price erosion in this area; conversely rising international oil costs reflect directly in this market. In the domestic orbit, Canadian crude oil surplus requirements are exported and compete with United States or foreign oil imports in the Puget Sound area of the west coast or in the Chicago/Detroit market. Minor discrepancies arise from time to time, but ultimately price movements in international values can be expected to be reflected in Canada's domestic price structure under free market conditions.

Discoveries in Canada's now producing regions have been rare in recent years since discovery potential diminishes as a province reaches more mature stages of exploration and large amounts of capital have been put at risk in promising Frontier regions off our west and east coasts, and in the north. Consequently, liquids production in currently producing regions is expected to peak in the mid '70's, then begin to decline, as shown on Chart 8.

New reserves in existing regions will be brought into production, but by 1990 production from currently producing regions, excluding tar

CHART 8

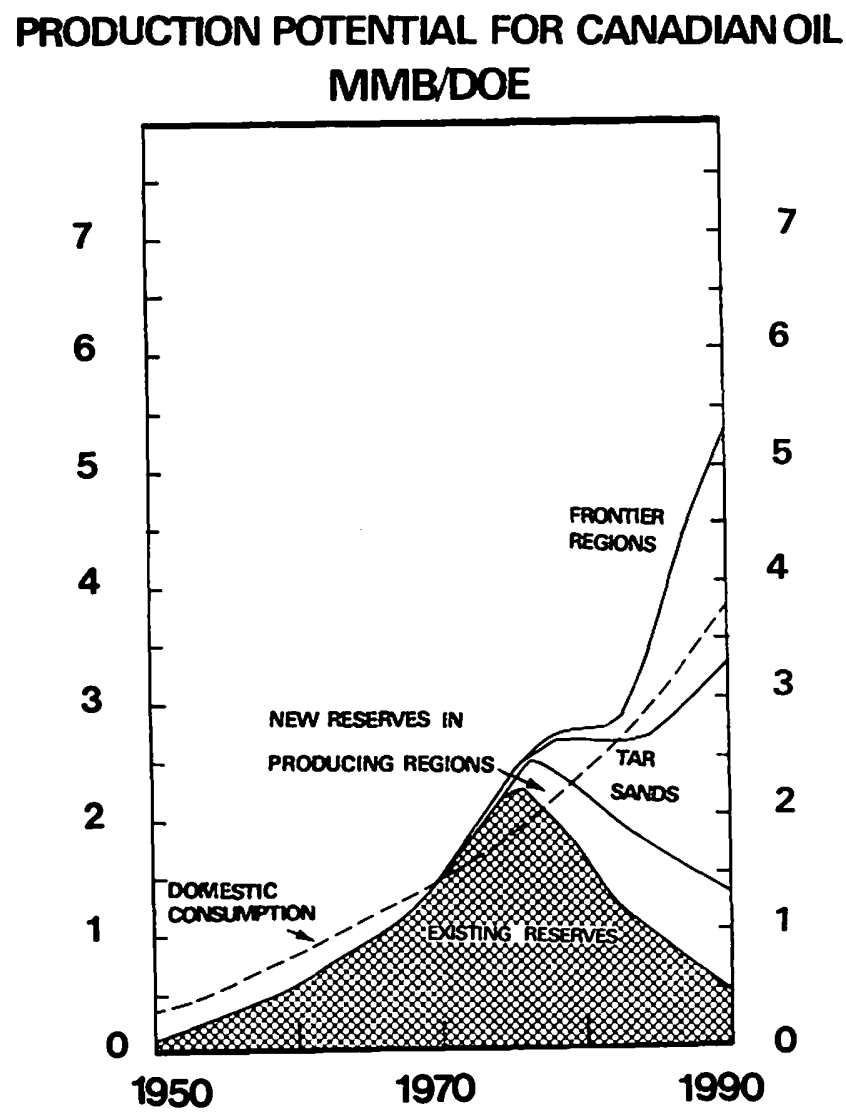


sands, is expected to decline to some 1.3 million barrels daily oil equivalent, i.e., about three-quarters of today's level.

The vast, and virtually untapped, reserves of the tar sands remain Canada's big trump card, estimated in the order of 300 billion barrels, of a new source of energy equal to about $45 \%$ of the known conventional oil reserves of the world. Of these, some 60 billion barrels can be recovered by mining techniques, with the remainder available by "in-situ" method of recovery. Admittedly tar sands will be developed at considerable capital cost, but several plants of varying sizes could be on stream and producing, by 1990 , nearly as much synthetic oil as Canada's entire conventional liquids production last year. Supplement this by anticipated discoveries in the Frontier regions and a new incentive for export will be created, admittedly won by costly investment in remote regions, requiring ingenious and expensive transportation links to market. Total availability is expected to be in excess of domestic requirements for many years, and provide a basis for further export trade, as shown in Chart 8.

Yet, despite these prospects of exportable surpluses, Canada can in no way hope to fill the growing United States energy gap, even at substantially higher price levels and a reasonable flow of oil and gas from the Arctic. For example, Canada today only provides $5 \%$ of the United States' requirement for oil and about $4 \%$ of its gas requirement. These can only increase marginally under a policy where exports are governed by declared surpluses.

\section{RESERVES AND PRODUCTION}

Glimpses into future energy requirements can be brought into perspective by looking at the adequacy of our resource base. One yardstick used in the industry is the life index, or, the relationship between proven reserves deemed commercially producible under today's techniques at today's price levels and annual production rates. This yardstick can be applied to known reserves of all conventional energy forms to highlight their relative importance. An examination of the non-hydrocarbon resources shown on Chart 9 is a logical starting point.

Coal, in terms of sheer volume of reserves, is the world's most important single potential source of fossil energy. The world's total mineable coal reserves, defined as $50 \%$ of coal actually present, have been estimated by the U.S. Geological Survey at 8.4 trillion short tons, or 24,900 billion barrels of oil equivalent. Of these known reserves, $56 \%$ are in the U.S.S.R. and nearly $20 \%$ in the U.S., compared with about $5 \%$ in Europe and none in Japan. If the required funds for expanded coal production are to be generated, its price will have to be much higher than in the past, and improved handling techniquesslurry pipelines on land and large bulk carriers for ocean shipmentand economic desulphurization means will be needed to keep coal relatively competitive with other energy forms. In short, the world's coal reserves can be brought into production at a cost.

On the other hand, the development of hydro electric potential is restricted, since it depends upon water availability near large consumption areas and requires heavy capital investment. The regions that have done the most to exploit their potential-North America and Western Europe-have the least undeveloped water power capacity. The 


\section{ENERGY RESERVES CHART 9 BILLIONS OF BARRELS OF OIL EOUNALENT}

\begin{tabular}{|c|c|c|c|}
\hline & WORLD & U.S. & CAMLADA \\
\hline \multicolumn{4}{|l|}{ HOH-OIL \& GAS } \\
\hline $\begin{array}{l}\text { COAL } \\
\text { HYURO } \\
\text { RUUCLEAR }\end{array}$ & $\begin{array}{l}24.900 \\
18.3 \text { P.A. } \\
50-19 J^{\text {(1) }}\end{array}$ & $\begin{array}{l}4.800 \\
0.312 \text { P.A. } \\
15-75 \text { (1) }\end{array}$ & $\begin{array}{l}290 \\
0.457 \text { P.A. } \\
25-80 \text { (2) }\end{array}$ \\
\hline \multicolumn{4}{|l|}{ OIL_\& GAS } \\
\hline $\begin{array}{l}\text { OIL \& WGL } \\
\text { NATURAL GAS } \\
\text { TAR SARDS } \\
\text { SHALE OIL }\end{array}$ & $\begin{array}{l}642 \\
300 \\
700 \\
200\end{array}$ & $\begin{array}{l}45 \frac{1}{2} \\
48 \\
- \\
80\end{array}$ & $\begin{array}{r}10 \\
9 \\
300 \\
-\end{array}$ \\
\hline $\begin{array}{l}\text { (1) LIGHT WAT } \\
\text { (2) CANDU REA }\end{array}$ & CTORS & & \\
\hline
\end{tabular}

two regions with the largest capacity for development-Africa and South America-find that a shortage of investment capital and a lower level of industrialization have to date inhibited development. New large hydro electric projects are likely in Canada, the Amazon Basin and Siberia over the next fifteen years. Advances in the technology of electricity transmission by the use of superconductors could promote development in more remote areas. In Canada, hydro electric power contributed $25.1 \%$ of the total 1971 primary energy requirements. Development of potential hydro sites by 1990 may well increase hydro generation by $100 \%$, leaving untapped another $200 \%$ for later use.

Currently, nuclear energy provides no more than about $10 \%$ of the total electricity generation in the U.K., and not.much more than $2 \%$ in the rest of Western Europe. In the U.S., nuclear energy provides no more than $1 \%$ of the country's total energy or about $1.6 \%$ of electricity generated. Here in Canada nuclear energy makes up $2.1 \%$ of total electricity generation. Throughout the world, the upward trend in the cost of fossil fuels generally should make large base-load nuclear plants fully competitive with fossil fuel plants from now on and provide the needed stimulus for nuclear plant additions. The development of the fast breeder reactor holds out hope that the industrialized world will not remain dependent upon diminishing, low cost, uranium supplies for nuclear energy. However, the first commercial prototype fast breeder plants are only just beginning to be built in North America, Western Europe and Japan. They will be unable to make any significant contribution to total energy supplies until the 1980's because of the long lead time involved. But, in the longer term, nuclear fusion will have virtually unlimited potential in producing energy for stationary uses.

Uranium reserves are thought of in terms of $\mathrm{U}_{3} 0_{8}$ and at $\$ 10 / \mathrm{lb}$., 232 thousand tons could be developed. Canada's foreseeable needs to 1990 
total about 42 thousand tons, suggesting we will have a continuing exportable surplus before taking into account discoveries likely to be added in the interim.

Turning now to hydrocarbons, shown on Chart 10, the world crude oil reserves in 1972 were estimated at 642 billion barrels. Production in 1971 was just over 50 million barrels per day, or about 18 billion barrels per year. Consequently, the world has a current reserve life index of 35 years-which is generally considered as more than adequate.

Crapt 10

\section{RESERVES versus PRODUCTION}

\begin{tabular}{|c|c|c|c|}
\hline & MORLD & $\begin{array}{c}\text { NORTH } \\
\text { AMERICA } \\
\end{array}$ & CANADA \\
\hline 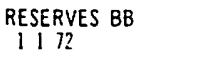 & 69? & 55.12 (IN P B ) & 10 (ex T S) \\
\hline $\begin{array}{l}\text { PRODUCTION BB } \\
1971\end{array}$ & 18 & 5 & 06 \\
\hline $\begin{array}{l}\text { CURRENT RESERVE } \\
\text { LIFE INDEX YEARS }\end{array}$ & 35 & 11.12 & 17.12 \\
\hline $\begin{array}{l}\text { IF RESERVES } \\
\text { MAINTAINED } 1980 \\
\text { RESERVE DEMAND } \\
\text { INDEX YRS }\end{array}$ & 18.12 & 7 & 11 \\
\hline
\end{tabular}

\begin{tabular}{|c|c|c|}
\hline & UNITED STATES & CANADA \\
\hline $\begin{array}{l}\text { RESERVES TCF } \\
1172\end{array}$ & 279 & 56 (ex Aictic) \\
\hline $\begin{array}{l}\text { PRODUCTION TCF } \\
197 !\end{array}$ & 22 & 2 \\
\hline $\begin{array}{l}\text { CURRENT RESERVE } \\
\text { LIFE INDEX YEARS }\end{array}$ & 12.12 & 28 \\
\hline $\begin{array}{l}\text { IF RESERVES } \\
\text { MAINTAINED } 1980 \\
\text { RESERVE DEMAND } \\
\text { INDEX YRS }\end{array}$ & 8 & 18 \\
\hline
\end{tabular}

However, world consumption of oil is growing at over $7 \%$ per year and should almost double to 34 billion barrels annually by the end of this decade. Total world oil consumption for the remainder of the 1970's will, therefore, total about 200 billion barrels. If reserves by the end of the 1970's are to equal the 642 billion barrels now available, the 200 billion barrels expected to be consumed will have to be replaced by new discoveries. This amount of oil would require the equivalent of over 10 times the reserves found in Canada to date.

Given this rate of discovery, the reserve life index by the end of the decade would still be reduced to $181 / 2$ years, simply because consumption rates will have nearly doubled. Indeed this rate of discovery is not likely to be possible from the areas of the world that have already been worked over. Consequently, the search is likely to be pushed into new areas, of which Canada's northern and offshore regions form a part.

The position outlined becomes more acute when narrowed down to 
North America since $85 \%$ of the world's reserves are currently located in the Middle East, Africa and the Communist Bloc countries. Only about $8.3 \%$, or $55^{1 / 2}$ billion barrels of the world's reserves are proven in the United States and Canada and this reserve includes a minimum estimate for the new discoveries on the North Slope of Alaska of 10 billion barrels.

Applying a similar reserve life index analysis to the North American scene, we find the reserve life index is now down to $11^{1 / 2}$ years with production running just under 5 billion barrels annually. Consumption in North America is expected to grow at about 5\% annually. Consequently, about $50 \%$ increase to $71 / 2$ billion barrels annually and total consumption of about $48^{1 / 2}$ billion barrels is in prospect over the balance of this decade. Even if this amount of oil can be replaced by new discoveries, the reserve life index in North America would be down to 7 years-a level which could tax the producing fields beyond their limits. Already, in early 1972, United States crude production reached a peak at a reserve life index of 11.

Canada is in a slightly better position than North America as a whole with reserves at the end of 1971 of 10 billion barrels, (excluding Tar Sands), a production rate of just under 600 million barrels per year and a reserve life index of $17^{1 / 2} 2$ years.

The question is, then, where are the necessary reserves to come from to support the production levels expected near the end of this decade? Excluding Alaska, the United States has been finding reserves at a rate of about 3 billion barrels per year, but this rate is declining and is not

CHART11

\section{ULTIMATE POTENTIAL CANADIAN RESERVES}

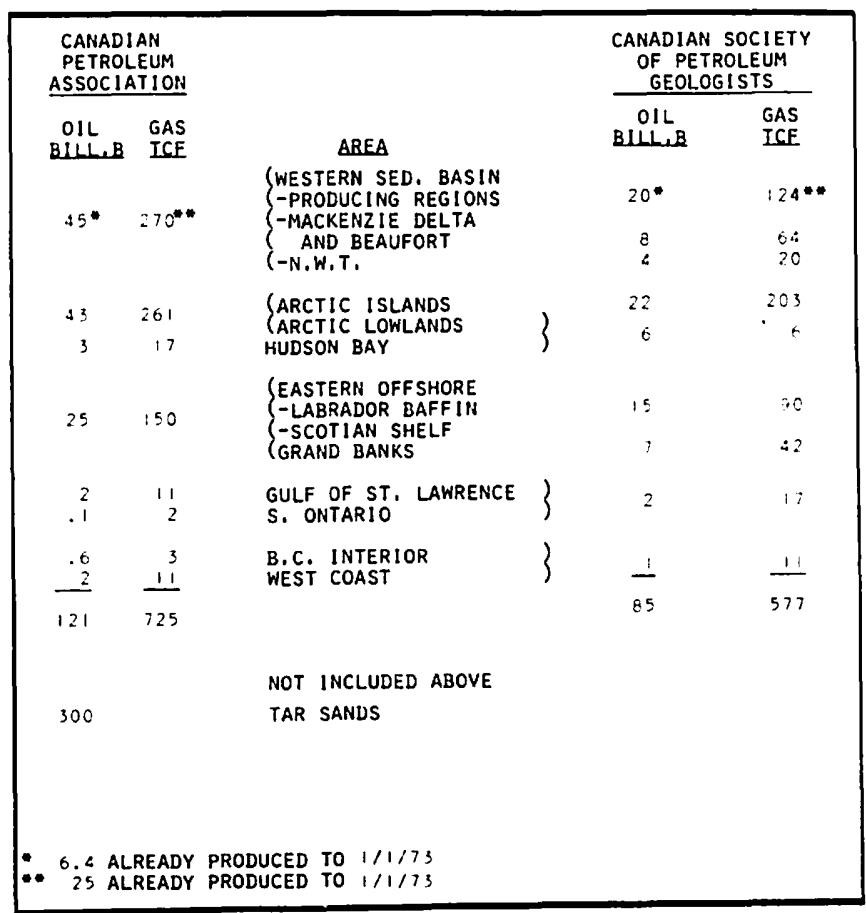


likely to be maintained over the next 8 years. The last large find in Canada was the discovery of Rainbow field in 1965. Reserve additions in 1971 amounted to 400 million barrels. Reserves declined in 1972.

A similar analysis of natural gas within North America would show that United States reserves at the end of 1971 totalled 279 trillion cubic feet, versus 1971 consumption of 22 trillion cubic feet, a reserve life index of $12^{1 / 2}$ years. If reserves are no more than maintained by the end of the current decade, and if it were possible to increase production to satisfy would-be demand, the index would shrink to 8 years. Similar conditions in Canada (before adding in any of the Arctic finds), show a current reserve life index of about 28 years, declining to 18 years by the end of the decade, after allowing for currently authorized exports.

Estimating reserves is at best hazardous. Chart 11 sets out the ultimate reserve potential for crude oil and gas reserves in Canada as estimated by the Canadian Petroleum Association and by the Canadian Society of Petroleum Geologists. Crude oil reserve estimates range from 85-121 billion barrels of crude, whereas gas reserve estimates range from 577-725 trillion cubic feet of natural gas. Both series of estimates exclude reserves of synthetic crude oil recoverable from Tar Sands, estimated separately by C.P.A. at 300 billion barrels.

Translating these into a conservative interpretation of the prospects to 1990 , I have set out the estimates on Chart 12.

CHART 12

ESTIMATED RESERVES/PRODUCTION POTENTIAL

1973-1990

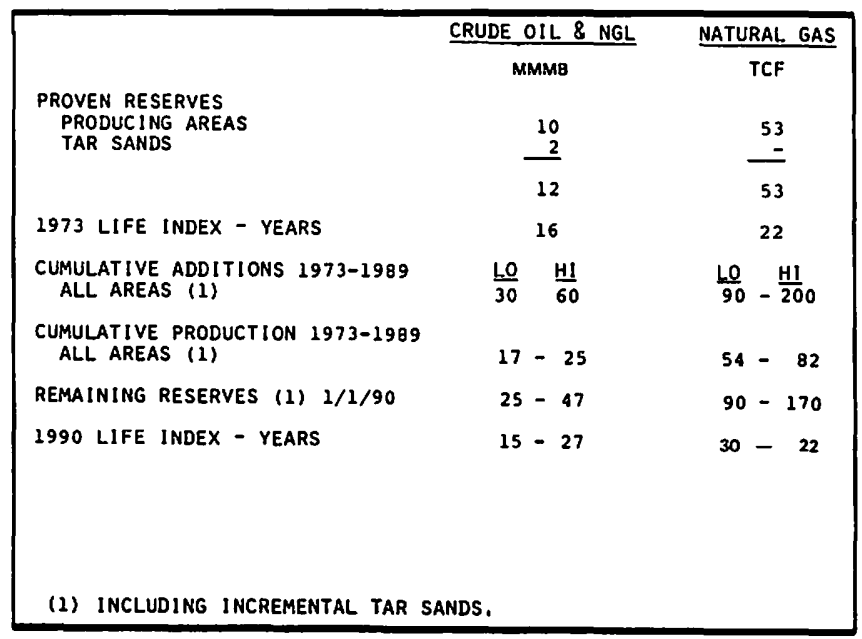

The estimates on Chart 12 show that Canada's liquid reserves of 10 billion barrels and currently developed Tar Sands reserves of 2 billion barrels are certain to be supplemented by new finds in existing areas and by additional tar sands development, totalling somewhere in the 
order of 20-30 billion barrels. Prospects for Arctic Islands and offshore finds are less well defined, but have been estimated at 10-30 billion barrels. Assuming an oil policy which permits production to reach the equivalent of total Canadian consumption but half the volume is exported to offset Eastern Canada imports in the high case and a lesser volume in the low case then 17-25 billion barrels would be consumed to 1989. The remaining expected reserve figure of $25-47$ billion barrels at 1990 rates of consumption would infer a life index of 15-27 years.

Natural gas reserves similarly projected show potential gross additions of 90-200 trillion cubic feet to today's 53 trillion cubic feet reserve level, offset by 54-82 trillion cubic feet of cumulative consumption to 1989 (depending upon export levels) leaving a 1990 reserve estimate of 90-170 trillion cubic feet, or a life index of 30-22 years at 1990 rates of consumption. The paradox of a lower life index of 22 years in the high reserve case results from a composite of a domestic life index of 30 and an export life index of 17.

The conclusions, even on this conservative basis, are significant: there is room for a policy in Canada which, in principle, permits an export of oil and gas resources in excess of indigenous needs.

\section{RESOURCE POLICY DEVELOPMENT}

So much for our review of supply and demand. Let us now address ourselves to some of the arguments we hear today about resource development. In dealing with the issues revolving around resource policy development, let us ask ourselves: What is being proposed? What problems can these proposals bring? What benefits can be derived?

\section{What is Proposed?}

The Canadian energy industry is, between now and 1990, required to invest about $4 \%$ of Canada's G.N.P. annually, or a cumulative investment totalling $\$ 230$ billion in current dollars assuming inflation of between 3.5 and $4 \%$ per annum. Of this amount $55 \%$, or some $\$ 125$ billion, will be spent in the normal course of events. This suggests that some $\$ 105$ billion of "incremental" expenditures will be required to develop sources of energy in Frontier regions and to satisfy our needs for additional electrical power. The first of these incremental efforts is the combined exploration and development outlay required in the Mackenzie Delta, Beaufort Sea, Arctic Islands, offshore areas and Alberta Tar Sands to find and bring into production the oil and gas potential of these regions. Although estimates vary widely on this, for current purposes let us say $\$ 50$ billion will go towards this effort between now and 1990 .

The second of these incremental efforts involves transportation systems-a gas pipeline from Prudhoe Bay and the Mackenzie Delta to the main Canadian gas transmission lines and an extension to Chicago. Current cost estimates range as high as $\$ 6$ billion. The development of other transportation facilities for oil and gas from the Frontier regions could total $\$ 14$ billion. These undertakings are mapped on Chart 13. Major projects to provide additional electrical power generation, transmission and distribution facilities (such as the James Bay Hydro Scheme, nuclear power plants, etc.) account for the remaining $\$ 35$ billion or so, of "incremental" expenditures. 
EXISTING AND PROPOSED PIPELINES

NATURAL GAS

CHART 13

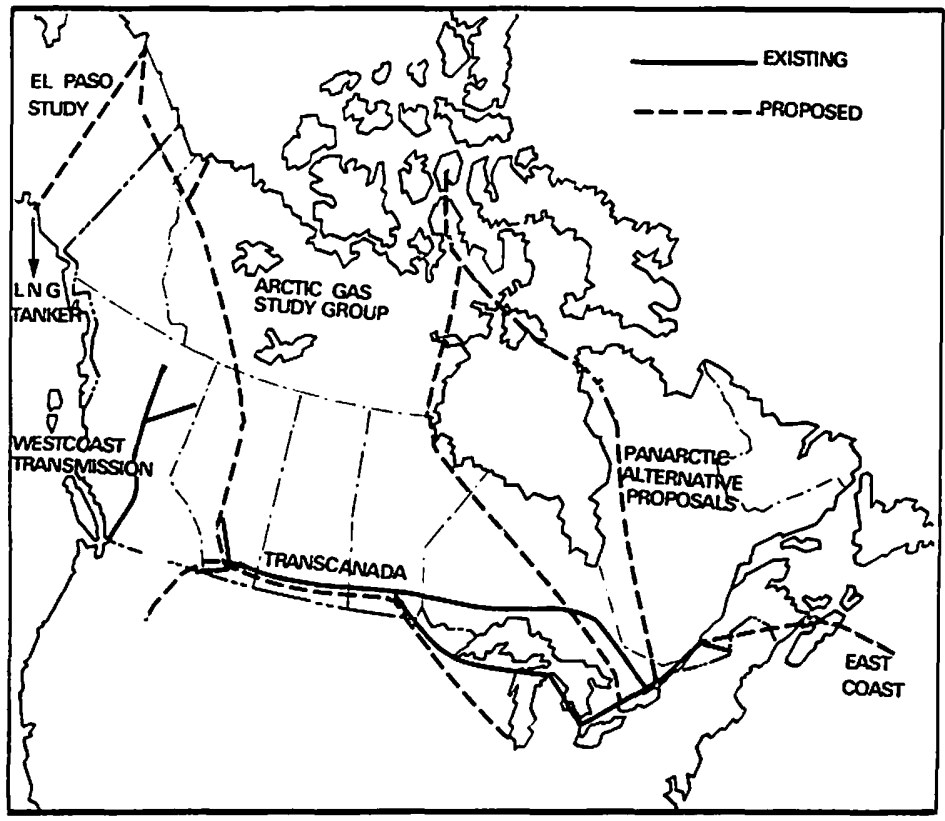

CRUDE OIL

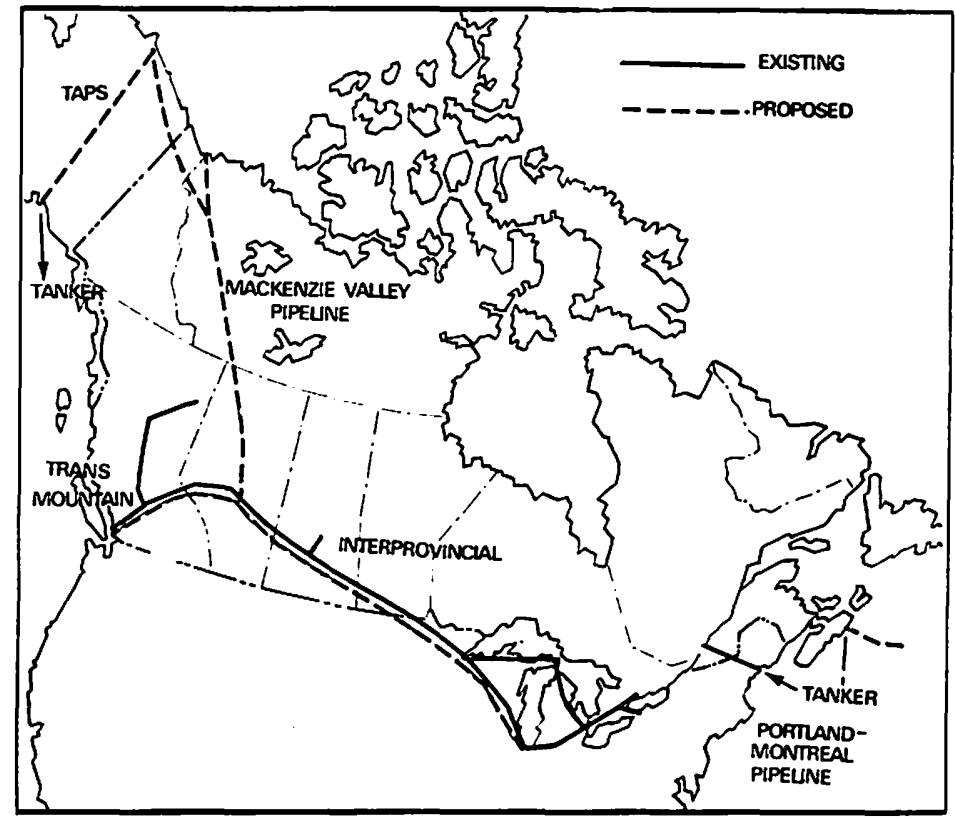

In dealing with the question of problems and benefits, we have heard most of the arguments to date in emotional terms. Save the country 
from ecological destruction! Conserve the resources for future generations of Canadians! Stop profiteering by foreign owners!

I would like to examine these questions on a policy plane. In doing so, I suggest four aspects hold the key-the availability of a secure energy supply; energy resource development for export market potential; net benefits to Canada; and equitable energy cost/price levels.

The availability of a secure energy supply in Canada is a function of geological opportunity, discovery and development of potential reserves, and in turn is a function of prudent fiscal policies in terms of royalties and incentives. Sedimentary basins of Canada possess the geological potential, and historically, royalty and incentive rates have brought forth risk capital to search for oil and gas under increasingly higher cost conditions. Future producer margins will have a significant bearing upon the rates at which capital for exploration will be forthcoming.

The other side of the coin in resource availability is the rate of consumption, or diminution of supply. To date, our society has prospered on the growth ethic. Conservationists and environmentalists argue that a thrift ethic should become national policy, i.e., that individual travel should be curtailed or replaced by mass transit; that home insulation should be improved; that design and end-use efficiency should be achieved through fiat or punitive taxation; that incremental cost pricing should displace average pricing or volume related discounting to achieve demand retardation and enhance security. Although most citizens could support such measures, however costly, in times of national crisis, it is doubtful if many would accept such restraint as proper long term national strategies unless this represented a truly economic alternative.

Meanwhile, risk capital has produced, and is producing, discoveries of oil and gas in excess of Canada's prudently foreseeable domestic needs. It follows that Canada has the potential for continued and expanded resource development for export markets. Because of the long distances involved in overland transport of oil in Canada, it would seem that volumetric self-sufficiency within a national context is both costly and unnecessary. Instead, self-sufficiency on balance represents a prudent national goal with imports of oil to Eastern Canada offsetting exports from the west. In 1971 Canada had an $18 \%$ net dollar advantage in its oil balance of payments in doing just this.

Canada has gas reserves, both developed and potential, which greatly exceed Canada's reasonably foreseeable needs. Such surpluses have a potential market at a good price in the United States where that country is experiencing current deficiencies. Action taken now will ensure access to those markets, will ensure lower unit transportation costs to all markets and ensure reasonable economics for the ultimate development of northern reserves for Canadian usage. Failure to avail ourselves of such an opportunity will induce faster substitution by the United States of coal gasification, and higher cost development of transportation systems from the Canadian North, if it indeed remains economic to bring northern reserves to limited Canadian markets where they will eventuallv be needed.

What are the net benefits to Canada? To mention only a few:

(1) continued resource development will ensure availability of energy 
under the best possible cost conditions for future generations of Canadians;

(2) development of the Arctic will establish a Canadian presence there and continue the assertion of Canada's sovereignty in that area;

(3) development of the North will lead to new mineral discoveries and provide still another opportunity for other economic multipliers to work their benefits through the Canadian economy;

(4) development of exportable surpluses of oil and gas will strengthen Canada's hand in reciprocal trade negotiations; and

(5) government revenues will be enhanced through these developments by royalties, corporate taxes and individual income taxes over the life of such ventures to provide substantial social capital formation to successive governments.

This leads to the fourth area of national policy issues-energy price levels or the recognition of equitable energy cost/price levels. Prices and costs have meaning in both absolute and relative terms. In a market economy, price equilibrates between the supply of a commodity and its consumption. It is also the best single arbiter of end-use, shrinking uneconomic uses in favour of those uses where greater utility (worth) is recognized.

On the international scene the world has experienced a surplus of crude oil with attendant downward pressures on price throughout much of the past two decades. Only in North America, where protectionist measures were adopted, have crude oil producers obtained higher realizations.

On the other hand, natural gas was in surplus in the United States prior to the ' 50 's, but by the middle of that decade most companies were looking hard for gas reserves. A surprise came in 1958 when regulation was introduced to control prices in the alleged long-term interests of consumers. In Western Canada natural gas prices were low in the early years, with a surplus of discovery and limited access to both domestic and export markets. As gas was connected to pipelines, United States and Canadian price levels tended to come into equilibrium in major markets.

Historical conditions have changed rapidly over the past three years. Economic growth in North America, Western Europe and Japan has greatly increased energy demands, while delays in nuclear development and ecological pressure for reduced or more costly energy development, reduced tax incentives in the United States and supply disruptions in Asia and Africa have constrained availability and led to abnormal demand growth for both oil and gas. As a consequence, oil prices are rising in response to both supply and demand considerations, as well as higher costs of exploration for alternative incremental supplies.

Natural gas prices have been disproportionately depressed relative to oil, when considered from the standpoint of equivalent heat value, lower equipment costs, or premium emission qualities in any major market. As a consequence, these fuels are undervalued in historic cost, replacement cost, or alternative fuel cost terms and must increase in price. How much they increase is a function of the relative competitiveness of energy supply/demand balance.

Notwithstanding price adjustments that have taken place, oil and gas remain among the best commodity values received in Canada today. 
To illustrate this, we can review how long an average Torontonian had to work in order to buy a gallon of gasoline, a gallon of heating oil and an equivalent amount of natural gas in 1960 and in 1972.

A gallon of gasoline required 13.2 minutes of work in 1960 and 9.0 minutes in 1972. Excluding Provincial road taxes and Federal sales tax, which have risen substantially over the period, the requirement was 8.4 minutes of work in 1960 and 5.4 minutes in 1972. A gallon of fuel oil required 6.0 minutes of work in 1960 and only 3.8 minutes in 1972, whereas an equivalent amount of natural gas went for 8.6 minutes of work in 1960 and 3.6 minutes in 1972. This sort of price performance level is testimony to the efficiency of the energy industries in the country.

Another argument we hear today about delaying or prohibiting development revolves around the environmental question. I believe at heart few men willingly foul their nest, and most are prepared to adopt acceptable standards of environmental and ecological protection. The businessman, however, has to be pragmatic. He cannot undertake developments for altruistic reasons if his competitor goes merrily ahead without incurring such costs. He cannot install costly emission control devices while his competitor does not. Here society, through government consulting with industry as to feasibility, has a responsibility to establish a sensible trade off between social benefit on one hand and the economic cost to society on the other. Indeed, industry throughout Canada has responded positively in participating with government in setting realistic environmental standards and in making investments to achieve those standards.

\section{AN INSTITUTIONAL FRAMEWORK}

So much for the socio-economic and political issues raised to date. What resolutions can we hope to achieve in the months and years ahead?

Obviously in the long chain of events from the finding and developing of raw material to the ultimate consumption of energy we can distinguish four basic interest groups with sometimes conflicting priorities. These four groups are: (1) the consumers themselves, (2) the governments of consuming areas or countries, (3) the governments of producing areas or countries, and (4) the energy companies who may be engaged in the entire system or only in parts of it.

Consumer priorities tend to stress unrestricted usage and availability at relatively low cost. Consumers in general are not prone to press for pollution free energy forms if the cost of such "clean" fuel falls upon them as individuals. Consumer area governments, somewhat more detached, see their priorities in terms of security of supply at competitive prices, to foster continuation of a competitive industrial base to pay for its energy imports through export of higher valued goods. Moreover, consumer area governments encourage importation of raw materials to provide source flexibility in the event of supply disruptions and to expand local employment. More often than not, they insist on environmental protection, but are frequently reluctant to concede that such costs must be borne by society as a whole in higher consumer prices or general tax revenues.

Producer area governments, on the other hand, anxious to develop 
their resource wealth, usually provide incentives to energy companies which induce them to undertake the necessary risks. Once resources are found, producer area government priorities often shift to actions designed to manage rates of production to generate higher realizations or economic rent, through royalty or other taxation, with a view to reinjecting these earnings either into an enhanced infrastructure or to expand secondary industry. In addition, producer area governments recognize both ecological protection and sound conservation practices at producer cost amongst their priorities, and in some areas provide recognition of, or compensation to, native peoples.

The energy companies, finding themselves in the midst of these conflicting views, also have a scale of priorities. They ask for an equal opportunity to compete and for relatively long-term stability of political and economic conditions. They abhor flagrant abrogation of contract or retroactive legislation. You will appreciate that such aspirations and objectives relate to the size of the investment which must be made, the enormity of the risks undertaken, and the time value of money, when one considers the long lead-time involved in energy resource development. Businessmen think it reasonable that reward be proportionate to risk undertaken, and that profit margins be sufficient both to reward the shareholders of the business and to generate new capital to perpetuate and expand the business. In the pursuit of this, they engage in sound engineering and safety practices and seek to trade under a market economy where price is the arbiter of economic end-use. Transportation, gas distribution and electric utility companies differ from the views of producers or integrated energy companies only when they find themselves caught in a profit margin bind between regulated rates and rising costs.

For reasons only history can reveal, Canada finds unity only when some issue threatens the nation as a whole, for example, the RussiaCanada hockey series. At other times, we seem to muddle through a balkanization of the country on many issues. Resource development is an issue which lends itself to regional schism.

The present jurisdictional division of powers in Canada also places considerable additional constraint on the way our resources are managed. As a layman, I hesitate to address a group of legal experts on this subject, but as I see it, there are two main dimensions:

(1) the ownership of the resource, and

(2) the factors related to them.

These dimensions give us the complicated matrix of legislative jurisdiction, the general principles of which are set out in Chart 14.

The split in jurisdictional authority vested in both the provincial and federal governments is evident in any examination of policies fashioned and enunciated by these administrations. As one wag said some time ago, "lawyers yet unborn will regard as forever blessed our Fathers of Confederation".

We Canadians, individually and collectively, seem ill-prepared to deal with the enormously important decisions on the horizon concerning energy development and management. To date, the research, the debate and the control of energy matters have been fragmentary. A need exists to place the energy issues in broader perspective. The large energy picture must embrace national issues in addition to provincial desires. 


\section{CHART 14 \\ LEGISLATIVE JURISDICTION AS RELATED TO RESOURCES}

\begin{tabular}{|c|c|c|c|c|c|}
\hline \multirow{3}{*}{\multicolumn{2}{|c|}{$\begin{array}{l}F=\text { FEDERAL } \\
P=\text { PROVINCIAL }\end{array}$}} & \multicolumn{4}{|c|}{ FACTORS AT ISSUE } \\
\hline & & \multicolumn{2}{|c|}{ LOCATION } & \multicolumn{2}{|c|}{ MOVEMENT } \\
\hline & & $\begin{array}{l}\text { INTRA } \\
\text { PROV. }\end{array}$ & $\begin{array}{l}\text { EXTRA. } \\
\text { PROV.: }\end{array}$ & $\begin{array}{l}\text { INTRA } \\
\text { PROV. }\end{array}$ & $\begin{array}{l}\text { EXTRA PROY. } \\
\text { COUNTRY }\end{array}$ \\
\hline \multirow{3}{*}{ OWINERSHIP } & $\begin{array}{l}\text { CROWN } \\
\text { FED. }\end{array}$ & $\mathbf{P}$ & $F$ & $P$ & $F$ \\
\hline & PRIVATE & $P$ & $F$ & $p$ & $F$ \\
\hline & $\begin{array}{l}\text { CROWN } \\
\text { PROV. }\end{array}$ & $P$ & $F^{* *}$ & $P$ & $F$ \\
\hline $\begin{aligned} \text { INC } & \text { BAS } \\
\cdots & \text { EXS }\end{aligned}$ & $\begin{array}{l}\text { TERR } \\
\text { THE } \\
\text { WS C }\end{array}$ & $x i$ & AND & & $\mathbf{T}$ \\
\hline
\end{tabular}

Foreign trade issues and the mapping of Canada's industrial strategy are both large questions in which energy has a role to play. Such a helicopter viewpoint will be difficult to achieve within the existing fragmented institutions which deal with energy policy and regulation in Canada today.

Canada's energy resources are a vast and appreciating asset from which all Canadians should derive future benefits. A national consensus must be reached on the future utilization of these valuable resources. In reaching a consensus, it is not suggested that the Federal Government should develop and impose a policy on the nation, but rather that a policy should emerge by careful consultation between the parties concerned.

This suggests that some form of National Energy Advisory Council could provide the forum for a constructive debate and the achievement of a modus vivendi. There are many possibilities for structuring such a Council-one suggestion appears schematically on Chart 15. Membership in such a council could include Federal and Provincial Governments, energy companies (explorers, producers, importers, refiners, marketers and distributors) public and private, energy consumers, environmentalists, conservationists and labour groups. This Advisory Council could work under the auspices of the Federal/Provincial Resource Ministers through a series of regional and interest group committees. Time is of the essence, and such an Advisory Council could, in the long run, prove to be the most expeditious way towards the achievement of a national consensus.

Without such a consensus, I predict that most energy development proposals, as they are processed through existing governmental 


\section{A FRAMEWORK FOR ACHIEVING NATIONAL CONSENSUS CHAFT 15}

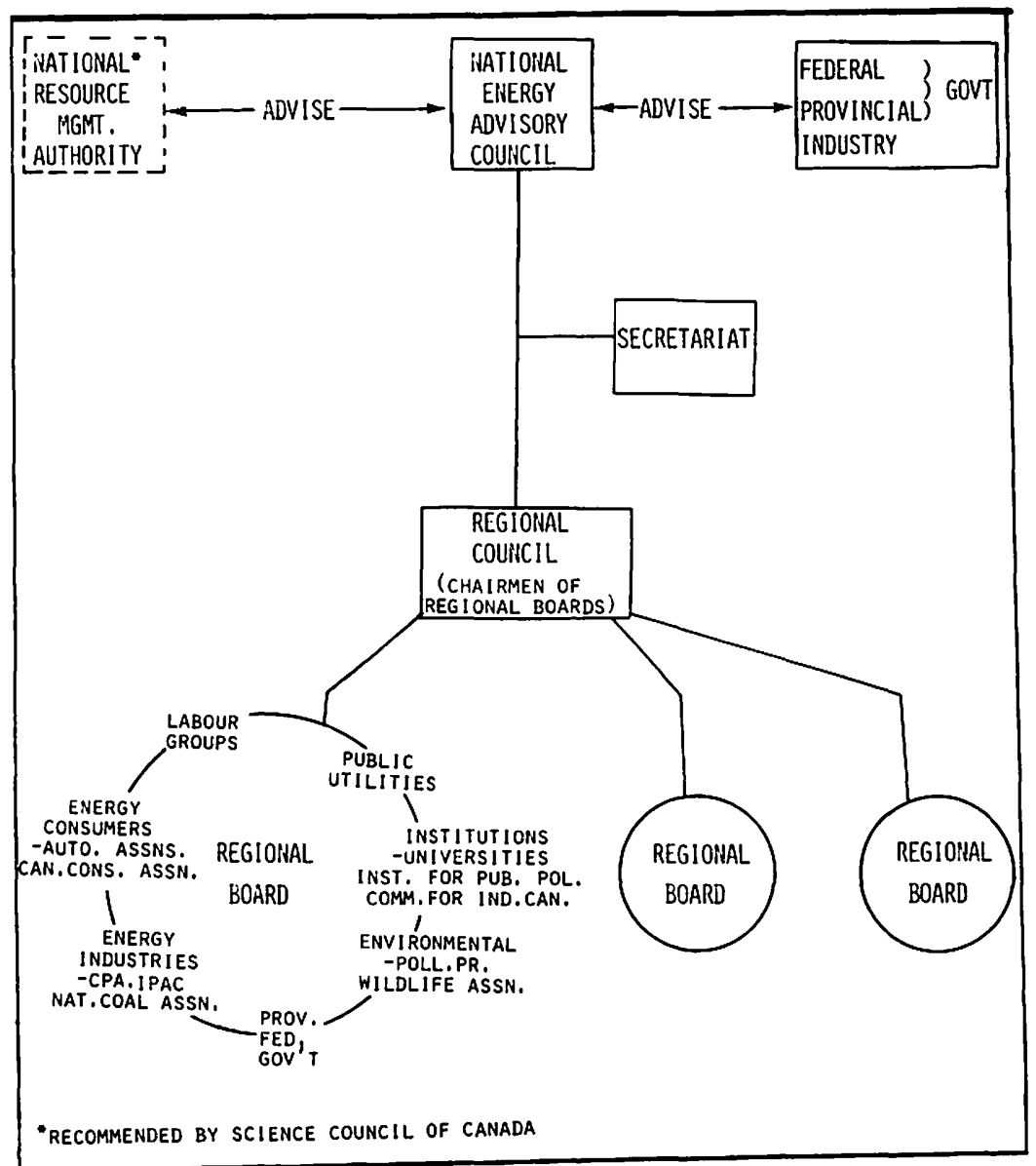

machinery, will provide growing evidence of the wide divisions which exist in the country on resource development; that such hearings as are held will provide opportunity for endless interest group posturing or procedural wrangling and that many of the issues that would normally be settled by people reasoning together will be pushed into our already burdened courts, where differences will be settled on points of law instead of national interest.

\section{SUMMARY}

Let me summarize the position as I have outlined it.

(1) World energy reserves are likely to prove adequate for many years to come. However, much of the world's energy will come from oil and many of these reserves are located in the volatile Middle East, some distance from the major markets of Western Europe, Japan and North America.

(2) Within North America, the United States has and will continue to have a growing dependency on outside energy supplies into the 1980's. 
The United States has the national capability of developing greater self-sufficiency by that time than is now perceived.

(3) Canada has adequate energy reserves for years to come, and has an opportunity to develop a trade policy based upon exportable surpluses.

(4) The early development of Canada's Frontier reserves will ensure continuing long range energy availability to Canadians under best possible cost conditions.

(5) Other net benefits to Canada include the continued assertion of a Canadian presence and sovereignty in the north, potential raw mineral discoveries, trade negotiation advantages and social capital formation potential.

(6) Rising energy costs will be reflected in rising prices, but a market economy will ensure continuing efficiency and best economic end-use. Oil and gas products are likely to provide excellent value received for years to come.

(7) Canada is fragmented by regional and special interest groups. Current jurisdictional and administrative groups proliferate. Some forum, not now provided, is needed to achieve a national consensus on energy resource development. Perhaps a National Energy Advisory Council, jointly sponsored by the Resource Ministers would be appropriate.

(8) Energy policy development in Canada in the seventies requires Canadians everywhere to show both vision and statesmanship to a degree seldom required in the nation's history. 